\title{
Correction to: Internal and marginal adaptation of high-viscosity bulk-fill composites in class II cavities placed with different adhesive strategies
}

\author{
Rainer Haak ${ }^{1}$ (D) Thomas Näke ${ }^{1} \cdot$ Kyung-Jin Park $^{1} \cdot$ Dirk Ziebolz $^{1} \cdot$ Felix Krause $^{1} \cdot$ Hartmut Schneider $^{1}$
}

Published online: 4 February 2019

(c) The Society of The Nippon Dental University 2019

\section{Correction to: Odontology \\ https://doi.org/10.1007/s10266-018-0402-1}

In the original publication of the article the paragraph "The four resin-based composites..." appearing below the "Materials and methods" section is incomplete. The correct paragraph is provided in this correction below:

The four resin-based composites were applied to the prepared cavities combined with each of the two adhesives (etch-and-rinse, ER; self-etch, SE). Table 1 shows the properties and composition of the materials used and supplementary table 1 summarizes the procedure of application.

The original article has been corrected.

Supplementary material 1 Restoration procedure according to manufacturer's recommendations
The original article can be found online at https://doi.org/10.1007/ s10266-018-0402-1.

Rainer Haak

rainer.haak@medizin.uni-leipzig.de

http://zahnerhaltung.uniklinikum-leipzig.de

Thomas Näke

thomas.naeke@medizin.uni-leipzig.de

Kyung-Jin Park

kyung-jin.park@medizin.uni-leipzig.de

Dirk Ziebolz

dirk.ziebolz@medizin.uni-leipzig.de

Felix Krause

felix.krause@medizin.uni-leipzig.de

Hartmut Schneider

hartmut.schneider@medizin.uni-leipzig.de

1 Department of Cariology, Endodontology

and Periodontology, University of Leipzig, Liebigstr.12,

04103 Leipzig, Germany 


\begin{tabular}{|c|c|c|}
\hline & Material & Workflow \\
\hline \multirow[t]{11}{*}{ Adhesive } & OptiBond FL & 1. Etching with $37.5 \% \mathrm{H}_{3} \mathrm{PO}_{4}(30 \mathrm{~s}$ for enamel, $15 \mathrm{~s}$ for dentin) \\
\hline & & $\begin{array}{l}\text { 2. Adaptation of matrix band (KerrHawe Lucifix }{ }^{\circledR} \text { Molar Bands Transparent, KerrHawe SA, Bioggio, } \\
\text { CH) }\end{array}$ \\
\hline & & 3. Active application of Primer for $15 \mathrm{~s}$ \\
\hline & & 4. Solvent evaporation with oil free air stream for at least $5 \mathrm{~s}$ \\
\hline & & 5. Application of Adhesive for $15 \mathrm{~s}$ \\
\hline & & 6. Gentle blowing for $3 \mathrm{~s}$ \\
\hline & & $\begin{array}{l}\text { 7. Light-cure from the occusal for } 20 \mathrm{~s}\left(1100 \mathrm{~mW} / \mathrm{cm}^{2} \pm 10 \% \text {; } \text { bluephase }^{\circledR}(\mathrm{G} 2) \text {, Ivoclar Vivadent AG, }\right. \\
\text { Schaan, Liechtenstein) }\end{array}$ \\
\hline & Xeno V+ & 1. Adaptation of matrix band (KerrHawe Lucifix ${ }^{\circledR}$ Molar Bands Transparent) \\
\hline & & 2. Active application of self-etch adhesive for $20 \mathrm{~s}$ \\
\hline & & 3. Gentle blowing for at least $5 \mathrm{~s}$ \\
\hline & & 4. Light-cure from the occusal for $10 \mathrm{~s}\left(1100 \mathrm{~mW} / \mathrm{cm}^{2} \pm 10 \%\right.$; bluephase $\left.{ }^{\circledR}(\mathrm{G} 2)\right)$ \\
\hline \multirow[t]{14}{*}{ Composite } & SonicFill & 1. Installing the MULTIflex coupling \\
\hline & & 2. Checking the pressure $(3.5 \pm 0.1$ bar $)$ \\
\hline & & 3. Attaching the SONICfill handpiece and inserting the Unidose Tips (power level 3) \\
\hline & & $\begin{array}{l}\text { 4. Application of the filling material in horizontal and oblique layers of } 5 \mathrm{~mm} \text { thickness max. with model- } \\
\text { ling instruments }\end{array}$ \\
\hline & & $\begin{array}{l}\text { 5. Light-cure from the occlusal, vestibular and oral surface for } 20 \mathrm{~s} \text { each }\left(1100 \mathrm{~mW} / \mathrm{cm}^{2} \pm 10 \% \text {; }\right. \\
\left.\text { bluephase }{ }^{\circledR}(\mathrm{G} 2)\right)\end{array}$ \\
\hline & Tetric EvoCeram & 1. Inserting the Cavifil into injector \\
\hline & Bulk Fill & $\begin{array}{l}\text { 2. Application of the filling material in horizontal and oblique layers of } 4 \mathrm{~mm} \text { thickness max. with model- } \\
\text { ling instruments }\end{array}$ \\
\hline & & $\begin{array}{l}\text { 3. Light-cure from the occlusal, vestibular and oral surface for } 10 \mathrm{~s} \text { each }\left(1100 \mathrm{~mW} / \mathrm{cm}^{2} \pm 10 \% \text {; }\right. \\
\left.\text { bluephase }^{\circledR}(\mathrm{G} 2)\right)\end{array}$ \\
\hline & $\mathrm{x}$-tra fil & 1. Inserting the Caps into dispenser \\
\hline & & $\begin{array}{l}\text { 2. Application of the filling material in horizontal and oblique layers of } 4 \mathrm{~mm} \text { thickness max. with model- } \\
\text { ling instruments }\end{array}$ \\
\hline & & 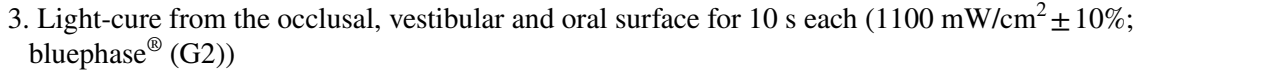 \\
\hline & Premise & 1. Inserting the Unidose into dispenser \\
\hline & & $\begin{array}{l}\text { 2. Application of the filling material in horizontal and oblique layers of } 2.5 \mathrm{~mm} \text { thickness max. with } \\
\text { modelling instruments }\end{array}$ \\
\hline & & $\begin{array}{l}\text { 3. Light-cure from the occlusal, vestibular and oral surface for } 10 \mathrm{~s} \text { each }\left(1100 \mathrm{~mW} / \mathrm{cm}^{2} \pm 10 \% \text {; }\right. \\
\left.\text { bluephase }^{\circledR}(\mathrm{G} 2)\right)\end{array}$ \\
\hline
\end{tabular}

Publisher's Note Springer Nature remains neutral with regard to jurisdictional claims in published maps and institutional affiliations. 